\title{
DESAIN SISTEM, JOB ORDER COSTING
}

\author{
Muhammad Idris DM \\ Fakultas Ekonomi Universitas Maritim Raja Ali Haji, Tanjungpinang, Kepulauan Riau, Indonesia
}

\begin{abstract}
ABSTRAK : Akuntansi manajemen merupakan suatu sistem pengolahan informasi keuangan yang digunakan untuk menghasilkan informasi keuangan bagi kepentingan pemakai intern organisasi. Sebagai salah satu tipe informasi, akuntansi manajemen merupakan tipe informasi kuantitatif yang menggunakan uang sebagai satuan ukuran, yang digunakan untuk membantu manajemen dalam pelaksanaan pengelolaan perusahaan. Akuntansi manajemen merupakan informasi keuangang yang merupakan keluaran yang dihasilkan oleh tipe akuntansi manajemen, yang dimanfaatkan terutama oleh pemakai intern organisasi..Sistem process costing digunakan dalam perusahaan yang memproduksi satu jenis produk dalam jumlah besardalam jangka panjang. Prinsip dasar dari proses costing adalah mengakumulasikan biaya dari operasi atau departemen tertentu selama satu periode penuh (bulanan, kuartalan, dan tahunan) dan kemudian membaginya dengan jumlah unit yang diproduksi selama periode tersebut..Sistem Job Order Costing juga dipergunakan secara luas dalam perusahaan jasa.Seperti rumah sakit, kantor konsultan hukum, studio bioskop, kantor akuntan, agen iklan, toko reparasi menggunakan sistem pengumpulan biaya dengan job order costing untuk keperluan akuntansi dan penagihan. Masalah pencatatan dan pembebanan biaya akan lebih kompleks pada saat perusahaan menjual berbagai macam produk dan jasa.
\end{abstract}

Kata kunci:Disain Sistem; Job Order Costing

ABSTRACT : Management accounting is a financial information processing system that is used to produce financial information for the interests of the organization's internal users. As one type of information, management accounting is a type of quantitative information that uses money as a unit of measurement, which is used to assist management in implementing company management. Management accounting is financial information which is the output produced by the type of management accounting, which is used primarily by internal users of the organization. Process costing systems are used in companies that produce one type of product in large quantities in the long run. The basic principle of the costing process is accumulating costs from certain operations or departments during a full period (monthly, quarterly, and yearly) and then dividing by the number of units produced during that period. The Job Order Costing system is also widely used in service companies. Like hospitals, legal consultant offices, cinema studios, accountant offices, ad agencies, repair shops use a system of collecting fees with job order costs for accounting and billing purposes. The problem of recording and charging costs will be more complex when the company sells various kinds of products and services.

Keywords:System Design; Job Order Costing

Email Address : midrisdm@yahoo.com 


\section{Pendahuluan}

Dengan semakin pesatnya perkembangan sektor transportasi dan telekomunikasi, semakin dekat terwujudnya globalisasi. Ekonomi negaranegara di seluruh dunia semakin terbuka dan pasar semakin berfungsi. Hubungan ekonomi antar negara di dunia semakin tergantung satu sama lainnya, sehingga batas-batas ekonomi antar negara semakin kabur.

Globalisasi menuntut perusahaanperusahaan di Indonesia untuk bersaing secara global, menuntut keunggulan perusahaan (enterprise excellence) agar perusahaanperusahaan tersebut bertahan hidup dan berkembang dalam jangka panjang di dalam menghadapi persaingan. Perlu kita sadari bahwa bagi perusahaan-perusahaan Indonesia, tidak perlu harus menjual produk dan jasa mereka ke luar negeri untuk berhadapan dengan persaingan tingkat dunia, namun persaingan global segera dihadapi begitu perusahaan memulai bisnisnya.

Untuk menjadi perusahaan yang memiliki keunggulan daya saing, salah satu persyaratan penting yang harus dimiliki oleh perusahaan adalah kemampuan untuk menjadi cost effective dalam menghasilkan produk dan jasa. Untuk menjadi perusahaan yang cost - effectiv, manajemen perusahaan senantiasa harus melakukan peningkatan (improvement) terhadap berbagai aktivitas yang digunakan untuk menghasilkan produk dan jasa serta menghilangkan aktivitas bukan penambah nilai., sehingga pelanggan hanya dibebani dengan biaya - biaya untuk aktivitas penambah nilai. Karena setiap produk atau jasa memerlukan aktivitas, dan setiap aktivitas mengkonsumsi sumber daya, maka sistem informasi yang mampu mencerminkan konsumsi sumber daya dalam berbagai aktivitas yang digunakan untuk menghasilkan produk atau jasa akan sangat bermanfaat bagi manajemen dalam perencanaan dan pengendalian aktivitas perusahaan.

Untuk memungkinkan manajemen memantau efektivitas berbagai aktivitas yang digunakan untuk menghasilkan produk dan jasa, mereka memerlukan sistem informasi yang mampu mencerminkan konsumsi sumber dayadalam berbagai aktivitas tersebut. Akuntansi manajemen merupakan sistem informasi yang dirancang untuk memenuhi kebutuhan manajemen dalam perencanaan dan pengendalian aktivitas perusahaan, agar perusahaan dapat mencapai tujuan yang telah ditetapkan.

Akuntansi dan manajemen adalah dua hal yang berkaitan. Meskipun kelihatannya membicarakan hal yang sama sekali berbeda, tetapi keduanya tetap berada di ranah yang sama. Akuntansi manajemen adalah sebuah sistem akuntansi yang memiliki kaitan dengan penggunaan informasi akuntansi oleh tingkat manajerial suatu organisasi. Manfaat akuntansi manajemen ini akan memberikan dasar pembuatan keputusan bisnis sehingga manajemen bisa lebih siap untuk mengelola dan melakukan fungsi pengontrolan.

Menghasilkan informasi keuangan untuk kepentingan manajemen (pihak intern perusahaan) dalam usaha untuk mencapai tujuan perusahaan (Rita Eni Purwanti \& Indah Nugraheni).Informasi tersebut diperlukan oleh manajemen untuk suatu bahan pertimbangan pengambilan keputusan manajemen serta melihat/menilai hasil-hasil yang sudah didapatkan suatu perusahaan.

Proses pengidentifikasi, mengukur dan melaporkan informasi ekonomi keuangan, untuk memungkinkan adanya suatu penilaian dan keputusan yang jelas dan tegas bagi manajemen yang menggunakan suatu informasi tersebut di mana titik sentralnya untuk pihak-pihak di dalam sebuah organisasi perusahaan. Misalnya : Kalkulasi biaya produk, Kalkulasi biaya suatu kegiatan, Kalkulasi biaya suatu department.

Salah satu bidang akuntansi yang tujuan utamanya yaitu untuk menyajikan suatu laporanlaporan sebagai satu satuan usaha untuk kepentingan pihak internal dalam rangka untuk 
melaksanakan proses manajemen yang meliputi suatu perencanaan, pengorganisasian, pengarahan dan pengendalian.

Membutuhkan informasi terkait dengan suatu aktifitas keuangan perusahaan seperti dalam pendanaan modal kerja, beban biaya cost of fund terhadap sejumlah modal kerja yang dibutuhkan oleh perusahaan, tingkat pengembalian investasi, tingkat pengembalian modal, rasio keuangan dan lain sebagainya.

Membutuhkan data informasi tentang mengenai rincian biaya Cost of good sold atau harga pokok produksi misalnya seperti total biaya produksi, biaya per unit produk, beban tenaga kerja langsung, serta dalam biaya overhead lainnya yang secara langsung mempunyai peran dalam proses produksi.

Membutuhkan data informasi semua komponen biaya terkait dalam suatu penetapan harga jual produk, penentuan sistem penjualan yang secara kredit atau tunai, beban komisi penjualan, marketing fee, serta informasi nilai discount untuk produk tertentu dalam suatu rangka peningkatan volume penjualan yang membutuhkan suatu informasi ini terkait dalam pengambilan kebijakan strategis perusahaan misalnya didalam penyusunan anggaran, ekspansi usaha, diversifikasi produk, maupun kebijakan investasi lainnya.

disediakan untuk membantu penulis dalam memformat naskah yang akan dikirim ke Jurnal Bahtera inovasi (Pengutipan: Mendeley). Penulis dapat menyalin-menempel tulisannya di template ini.Untuk menyalin-menempel teks dari sumber, diharapkan untuk menggunakan fasilitas 'Paste Special' pada Microsoft Word dan pilih 'Unformatted Text' untuk mempertahankan format teks dan paragraf pada template ini.

Bagian pendahuluan terutama berisi: (1) permasalahan penelitian; (2) rangkuman kajian teoritik yang berkaitan dengan masalah yang diteliti (3) wawasan dan rencana pemecahan masalah; (4) rumusan tujuan penelitian. Pada bagian ini kadang-kadang juga dimuat harapan akan hasil dan manfaat penelitian. Panjang bagian pendahuluan sekitar 2-3 halaman dan diketik dengan 1,15 spasi (atau mengikuti ketentuan penulisan jurnal ilmiah tempat artikel tersebut hendak diterbitkan).Template untuk format artikel ini dibuat dalam MS Word, dan selanjutnya disimpan dalam format $d o c$ atau docx. Batang tubuh teks menggunakan font: Times New Roman 11, regular, spasi 1.15, spacing before $0 \mathrm{pt}$, after $0 \mathrm{pt}$ ).

\section{Landasan Teori}

Akuntansi

Manajemen

merupakansuatusistem akuntansi yang memiliki kegunaan untk menyajikan laporan keuangan untuk kepentingan tertentu, di antaranya adalah untuk pihak internal perusahaan, contohnya adalah manajer keuangan, manajer pemasaran, manajer produksi serta pihak internal lainnya. Informasi ini nantinya akan sangat bermanfaat untuk dijadikan pedoman dalam pengambilan kebijakan di masa yang akan datang dengan didasarkan pada data historis serta laporan keuangan.

Chartered Institute of Management Accountant (1994:30) mengemukakan Akuntansi manajemen adalah Penyatuan bagian manajemen yang mencakup penyajian dan penafsiran informasi yang digunakan untuk perumusan strategi, aktivitas perencanaan dan pengendalian, pembuatan keputusan, optimalisasi penggunaan sumber daya, pengungkapan kepada pemilik dan pihak luar, pengungkapan kepada pekerja, dan pengamanan asset.

Menurut Chartered Institute of Management Accountants (CIMA), akuntansi manajemen adalah proses identifikasi, pengukuran, akumulasi, analisis, penyusunan, interpretasi, dan komunikasi informasi yang digunakan oleh manajemen untuk merencanakan, mengevaluasi, dan pengendalian dalam suatu entitas dan untuk memastikan sesuai dan akuntabilitas penggunaan sumber daya 
tersebut. Akuntansi manajemen juga meliputi penyusunan laporan keuangan untuk kelompok non-manajemen seperti pemegang saham, kreditur, badan pengatur dan otoritas pajak.

Horngren (1993:) mengatakan akuntansi manajemen diartikan sebagai "proses identifikasi, pengukuran, akumulasi, analisa, penyiapan, penafsiran, dan komunikasi tentang informasi yang membantu masing-masing eksekutif untuk memenuhi tujuan organisasi”.

Halim dan Supomo (2000) akuntansi manajemen merupakan kegiatan yang menghasilkan informasi keuangan untuk manajemen sebagai dasar pengambilan keputusan dalam menjalankan fungsi manajemen.

Mulyadi (2001) berpendapat akuntansi manajemen merupakan informasi keuangan dihasilkan oleh tipe akuntansi manajemen, yang dimanfaatkan oleh pemakai intern entitas.

Halim dan Supomo menyatakan bahwa Akuntansi manajemen merupakan suatu kegiatan yang menghasilkan suatu informasi keuangan untuk manajemen sebagai dasar untuk pengambilan keputusan dalam menjalankan fungsi manajemen.

Menurut Charles T. Homgren menyatakan bahwa Akuntansi manajemen (Management Accounting) ialah suatu proses identifikasi, pengukuran, akumulasi, analisa, penyiapan, penafsiran, dan komunikasi tentang informasi yang membantu masing-masing eksekutif untuk memenuhi suatu tujuan organisasi.

Akuntansi Manajemen merupakan suatu kegiatan berproses yang menghasilkan informasi keuangan bagi manajemen untuk pengambilan keputusan ekonomi dalam melaksanakan fungsi manajemen.

Secara Umum akuntansi manajemen adalah bagian dari akuntansi yang bertujuan membantu manajer untuk menjalankan tiga fungsi pokoknya, yaitu perencanaan, pengendalian, dan pengambilan keputusan sekaligus memberikan informasi kepada pihak- pihak internal untuk mencapai tujuan organisasinya.

Terdapat dua tipe akuntansi yaitu akuntansi keuangan dan akuntansi manajemen. Akuntansi manajemen memiliki dua arti yaitu sebagai suatu tipe akuntansi dan sebagai suatu tipe informasi. Akuntansi manajemen memiliki karakteristik yang sangat berbeda dengan akuntansi keuangan.

Akuntansi dapat dipandang sebagai suatu sistem yang mengolah masukan berupa data operasi dan data keuangan untuk menghasilkan keluaran berupa informasi akuntansi yang dibutuhkan pemakai. Akuntansi sebagai suatu sistem pengolahan informasi keuangan dapat dilihat pada gambar berikut :

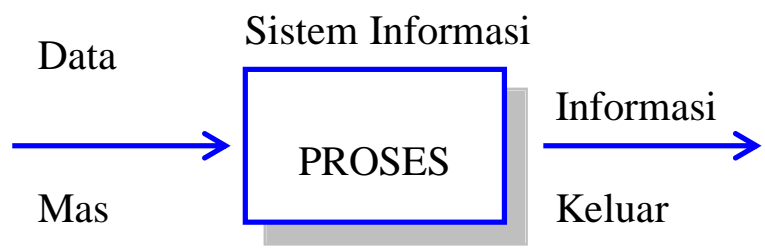

Sebagai salah satu tipe akuntansi, akuntansi manajemen merupakan suatu sistem pengolahan informasi keuangan yang digunakan untuk menghasilkan informasi keuangan bagi kepentingan pemakai intern organisasi. Sebagai salah satu tipe informasi, akuntansi manajemen merupakan tipe informasi kuantitatif yang menggunakan uang sebagai satuan ukuran, yang digunakan untuk membantu manajemen dalam pelaksanaan pengelolaan perusahaan. Akuntansi manajemen merupakan informasi keuangang yang merupakan keluaran yang dihasilkan oleh tipe akuntansi manajemen, yang dimanfaatkan terutama oleh pemakai intern organisasi. Untuk menggambarkan sudut pandang yang melukiskan tentag akuntansi manajemen dapat dilihat pada gambar berikut :

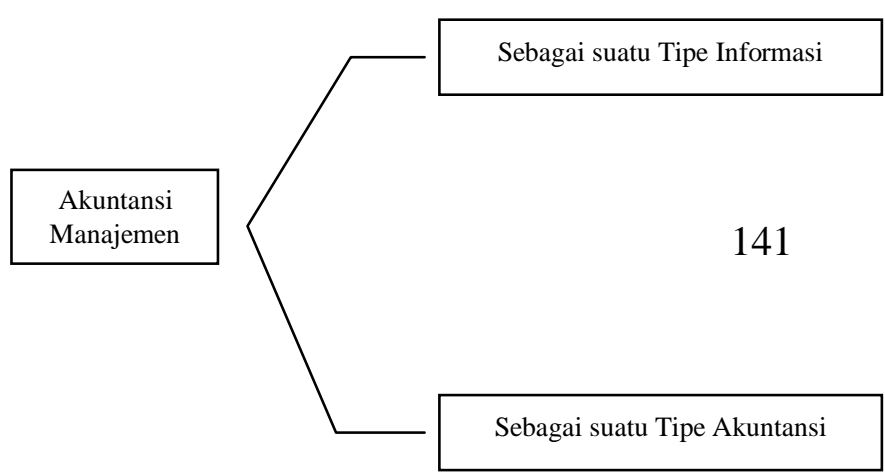


Oleh karena itu Akuntansi manajemen bertujuan menghasilkan informasi keuangan untuk pihak manajemen. Jenis informasi yang diperlukan berbeda dengan informasi yang diperlukan pihak luar. Umumnya informasi yang dihasilkan bersifat mendalam dan tidak dipublikasikan kepada pihak luar. Tujuan akuntansi manajemen secara umum anata lain adalah: ${ }^{1}$ Menyediakan informasi yang diperlukan dalam penetuan harga pokok jasa, produk, dan tujuan lain yang diinginkan oleh manajemen; ${ }^{2}$ Menyediakan informasi yang digunakan dalam perencanaan, pengendalian, pengevaluasian, dan perbaikan berkelanjutan; $\quad{ }^{3}$ Menyediakan informasi untuk pengambilan keputusan. Informasi akuntansi manajemen membantu mengidentifikasi suatu masalah, menyelesaikannya, serta mengevaluasi kinerja. Jadi, informasi akuntansi manajemen dibutuhkan dan dipergunakan dalam semua tahapan manajemen, termasuk perencanaan, pengendalian, dan pengambilan keputusan.

Proses Costing dan Job Order Costing;

Dalam menghitung banyak biaya produk atau jasa, manajer dihadapkan dengan masalah yang sulit. Sejumlah biaya (seperti sewa) tidak mengalami perubahan besar dari bulan ke bulan sedangkan produksi selalu berubah - ubah sesuai dengan kegiatan produksi dari bulan ke bulan. Selanjutnya mengenai variasi produksi, perusahaan dapat memproduksi berbagai jenis produk dengan menggunakan peralatan yang sama. Dalam kondisi seperti ini, apakah mungkin dapat menentukan secara akurat biaya produk atau jasa ? Dalam praktik, pembebanan biaya ke produk dan jasa dilakukan dengan membuat rata - rata untuk antar waktu dan antar produk. Cara untuk membuat rata - rata sangat tergantung pada tipe proses produksi yang terkait. Dua sistem costing biasanya digunakan dalam manufaktur dan di sejumlah perusahaan jasa; kedua sistem tersebut biasanya disebut process costing dan job order costing.

Sistem process costing digunakan dalam perusahaan yang memproduksi satu jenis produk dalam jumlah besardalam jangka panjang. Prinsip dasar dari proses costing adalah mengakumulasikan biaya dari operasi atau departemen tertentu selama satu periode penuh (bulanan, kuartalan, dan tahunan) dan kemudian membaginya dengan jumlah unit yang diproduksi selama periode tersebut. Perhitungan untuk process costing adalah sebagai berikut :

$$
\text { BiayaPerUnit }=\frac{\text { Totalbiaya produksi }}{\text { Unit } \operatorname{Pr} \text { oduksitotal }}
$$

Karena setiap unit produk (galon, pon, botol) tidak dapat dibedakan dengan unit produk lainnya, setiap unit dibebani biaya yang sama untuk setiap periodenya. Secara umum teknik costing tersebut berarti bahwa setiap biaya rata rata per unit yang ditetapkan untuk unit yang homogen mengalir terus secara kontinyu sepanjang proses produksi.

\section{Kerangka Pikir}

\section{Job Order Costing}

Sistem job order costing digunakan untuk perusahaan yang memproduksi bermacam produk selama periode tertentu. Sebagai contoh, perusahaan pakaian Levi Strauss membuat berbagai jenis produk pakaian jins baik untuk pria dan wanita. Suatu pesanan khusus misalnya berisi 1000 unit celana jins dengan model A312 ukuran pinggang 32. Pesanan sebanyak 1000 unit disebut satu batch atau satu pekerjaan atau job.Dalam sistem job order costing, biaya ditelusuri dan dialokasikan ke pekerjaan dan biaya untuk menyelesaikan pekerjaan tersebut dibagi dengan jumlah unit yang dihasilkan untuk menghasilkan harga rata - rata per unit.

Sistem Job Order Costing juga dipergunakan secara luas dalam perusahaan jasa.Rumah sakit, kantor konsultan hukum, studio bioskop, kantor akuntan, agen iklan, toko reparasi menggunakan sistem pengumpulan biaya dengan job order costing untuk keperluan akuntansi dan penagihan. Masalah pencatatan dan pembebanan biaya akan lebih kompleks 
pada saat perusahaan menjual berbagai macam produk dan jasa.

Tahapan aktivitas dalam Job Order Costing dapat digambarkan dalam diagram sebagai berikut :

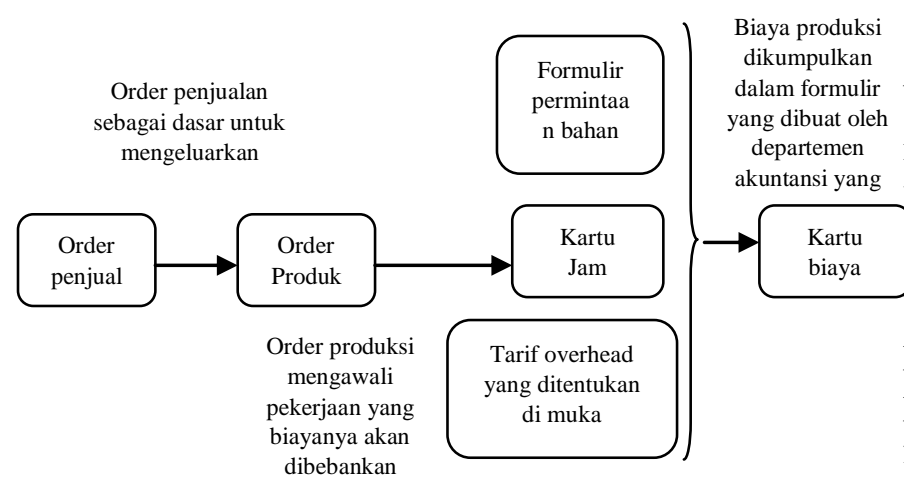

Karena produknya bermacam - macam, biayanya juga berbeda - beda. Konsekuensinya, biaya harus dicatat untuk masing - masing produk atau pekerjaan. Sebagai contoh, jaksa dalam permasalahan kriminal akan memiliki catatan biaya untuk masing - masing kliennya. Di perusahaan Levi Strauss di atas akan membuat catatan yang terpisah untuk setiap pesanan tertentu baik dari segi model, ukuran, dan warna jin. Oleh karenanya dalam sistem job order costing lebih banyak dibutuhkan penanganan dibandingkan process costing.

Pada umumnya perusahaan membagi biaya produksi menjadi tiga yaitu :

\section{1) Bahan Langsung}

Yaitu bahan yang menjadi bagian tak terpisahkan dari produk jadi dan dapat ditelusuri secara fisik dan mudah ke produk tersebut. Termasuk dalam hal ini misalnya tempat duduk di pesawat Boeing yang dibeli dari subkontraktor yang kemudian dipasang di pesawat - pesawat komersialnya. Termasuk juga motor elektris Panasonic yang terbuat dari timah yang digunakan untuk pemutar dalam CD player.

\section{2) Tenaga Kerja Langsung}

Istilah biaya tenaga kerja langsung digunakan untuk biaya tenaga kerja yang dapat ditelusuri dengan mudah ke produk jadi. Tenaga kerja langsung biasanya juga disebut juga "touch labor" karena tenaga kerja langsung melakukan kerja tangan atas produk pada saat produksi. Biaya tenaga kerja misalnya adalah tenaga kerja bagian perakitan seperti halnya biaya untuk tukang kayu, tukan batu dan operator mesin.

\section{3) Overhead Pabrik}

Biaya overhead merupakan elemen ketiga biaya manufaktur, termasuk seluruh biaya manufaktur yang tidak termasuk dalam bahan langsung dan tenaga kerja langsung. Biaya pverhead pabrik termasuk bahan tidak langsung, tenaga kerja tidak langsung, pemeliharaan dan perbaikan peralatan produksi, listrik dan penerangan, pajak properti, penyusutan, asuransi fasilitas-fasilitas produksi.

\section{Pengukuran Biaya}

\section{a. Mengukur Biaya Bahan Langsung}

Yost Precision Machining adalah perusahaan kecil yang berlokasi di Michigan yang khusus memproduksi komponen metal dengan presisi tinggi yang nantinya dapat digunakan mulai dari eksplorasi bawah laut sampai pemicu kelembaban dalam air bagi mobil.

Yost Precision Machining setuju untuk membuat kopel untuk Loops Unlimited, perusahaan yang membuat roller coaster.Kopel tersebut akan digunakan sebagai komponen roller coaster dan menjadi komponen yang sangat penting untuk menjaga kinerja dan keamanan pengendara. Yost Precision Machining membutuhkan empat konektor G7 dan dua Housing M46 untuk membuat dua kopel untuk Loops Unlimited.Jika pesanan ini adalah produk standar, akan ada dokumen kebutuhan barang. Dokumen kebutuhan barang adalah dokumen yang berisi tipe dan kuantitas dari masing - masing bahan yang digunakan untuk menyelesaikan setiap unit produk. Dalam kasus ini tidak ada dokumen kebutuhan barang, sehingga staf produksi di Yost menentukan kebutuhan bahan dari blue print / cetak biru yang dikirimkan oleh konsumen. Setiap kopel membutuhkan dua konektor dan satu housing 
sehingga untuk membuat dua kopel dibutuhkan empat konektor dan dua housing.

Jika sudah ada kesepakatan dengan konsumen mengenai kuantitas, harga dan pengiriman pesanan, dibuat formulir order produksi. Departemen produksi kemudian menyiapkan formulir kebutuhan barang atau permintaan barang. Formulir kebutuhan barang adalah dokumen sumber yang berisi spesifikasi tipe dan kuantitas bahan yang dikeluarkan dari gudang, dan identifikasi pekerjaan untuk membebankan biaya bahan. Formulir tersebut berperan sebagai alat pengendali bahan yang masuk ke dalam produksi dan juga sebagai bahan oleh akuntansi. Administrator gudang tidak diijinkan mengeluarkan material tanpa formulir permintaan bahan yang telah diotorisasi.

Setelah mendapatkan pemberitahuan bahwa order produksi telah dibuat, Departemen akuntansi akan menyiapkan kartu biaya, yaitu formulir yang disiapkan untuk setiap pekerjaan yang diterima. Kartu biaya berisi data bahan, tenaga kerja dan overhead yang dibebankan ke pesanan yang diterima.

Sesudah bahan langsung diterima, Departemen Akuntansi mencatat biaya secara langsung ke dalam kartu biaya. Biaya sebesar \$ 660 untuk bahan langsung yang ditunjukkan dalam formulir permintaan bahan dibebankan ke kartu biaya pesanan dengan kode 2B47. Nomor formulir permintaan bahan juga dicatat dalam kartu biaya untuk mempermudah identifikasi dokumen sumber yang menjadi dasar pembebanan biaya bahan langsung.

Selain itu untuk membantu membebankan biaya ke setiap pekerjaan, kartu biaya juga menjadi salah satu dokumen yang penting dalam catatan rinci pekerjaan dalam proses yang nantinya akan ditambahkan dalam saldo pekerjaan dalam proses.

\section{b. Mengukur Biaya Tenaga Kerja Langsung}

Biaya tenaga kerja langsung ditangani dengan metode yang sama seperti halnya biaya bahan langsung. Tenaga kerja langsung merupakan pembebanan tenaga kerja yang dapat dengan mudah ditelusuri ke pekerjaan tertentu. Tenaga kerja yang tidak dapat dengan mudah ditelusuri ke pekerjaan diperlakukan sebagai bagian dari overhead pabrik. Kategori tersebut disebut sebagai tenaga kerja tidak langsung. Tenaga kerja tidak langsung tersebut meliputi pemeliharaan, supervisi dan kebersihan.

Para pekerja menggunakan kartu jam kerja untuk mencatat waktu yang mereka gunakan untuk setiap pekerjaan dan tugas - tugas lainnya. Kartu jam kerja yang lengkap berisi ringkasan aktivitas tenaga kerja setiap jamnya. Pada saat mengerjakan pekerjaan tertentu, pekerja akan memasukkan nomor pekerjaan ke dalam kartu jam kerja dan mencatat jumlah waktu yang dibutuhkan untuk menyelesaikan pekerjaan tersebut. Pada saat tidak diberi pekerjaan yang pada dasarnya dapat dikategorikan sebagai biaya tenaga kerja tidak langsung seperti (pemeliharaan mesin) dan jumlah jam yang digunakan untuk melaksanakan tugas tersebut. Kartu jam kerja harian adalah dokumen sumber yang digunakan sebagai dasar untuk memasukkan biaya tenaga kerja ke dalam catatan akuntansi.

Sistem tersebut di atas merupakan metode pencatatan dan posting biaya tenaga kerja secara manual. Beberapa perusahaan mengandalkan sistem akuntansi komputer dan tidak lagi mencatat jam tenaga kerja secara manual dalam lembaran kertas. Salah satu pendekatan sistem komputer adalah menggunakan bar code untuk memasukkan data - data ke dalam komputer. Komputer dengan teknologi seperti bar code dapat menghilangkan aktivitas pembukuan rutin yang membosankan sekaligus meningkatkan ketepatan waktu dan keakuratan.

\section{c. Pembebanan Overhead Pabrik}

Overhead pabrik harus dimasukkan bersama - sama dengan biaya bahan langsung dan tidak langsung ke dalam kartu biaya karena overhead pabrik juga termasuk biaya produk. Meskipun demikian pembebanan overhead 
pabrik untuk setiap unit produk dapat menjadi tugas yang sulit. Ada tiga alasan yaitu: ${ }^{1)}$ Overhead pabrik adalah biaya tidak langsung. Hal ini berarti tidak mungkin atau sangat sulit untuk menelusuri biaya ini ke produk atau pekerjaan tertentu; ${ }^{2)}$ Overhead pabrik terdiri atas berbagai macam jenis biaya mulai dari paselin untuk mesin sampai gaji tahunan manajer pabrik; ${ }^{3)}$ Meskipun output produksi berfluktuasi, biaya overhead pabrik relatif tetap karena adanya biaya tetap.

Dengan adanya masalah - masalah tersebut, cara untuk membebankan overhead ke produk adalah dengan menggunakan proses alokasi. Alokasi biaya overhead dapat dilakukan dengan memilih basis alokasi yang umumnya digunakan untuk perusahaan manufaktur maupun perusahaan jasa. Basis alokasi adalh suatu ukuran seperti jam kerja langsung (JKL) atau jam mesin (JM) yang digunakan untuk membebankan biaya overhead ke produk atau jasa.

Basis alokasi umumnya digunakan adalah jam kerja langsung dan biaya tenaga kerja langsung. Selain itu jam mesin ataupun unit produk (untuk perusahaan yang hanya memproduksi satu jenis produk) biasanya juga dapat digunakan untuk mengalokasikan biaya overhead.

Basis alokasi digunakan untuk menghitung tarif overhead yang ditentukan di muka dengan cara seperti berikut :

\begin{tabular}{|c|c|c|c|c|}
\hline $\begin{array}{l}\text { Overhead yang } \\
\text { ditetapkan } \\
\text { Untuk pekerjaan } \\
\text { tertentu }\end{array}$ & $=$ & $\begin{array}{c}\text { Tarif overhead } \\
\text { yang } \\
\text { ditentukan di } \\
\text { muka }\end{array}$ & $X$ & $\begin{array}{l}\text { Jumlah basis } \\
\text { alokasi yang terjadi } \\
\text { dakan suatu } \\
\text { pekerjaan }\end{array}$ \\
\hline
\end{tabular}

Sebagai contoh, jika tarif overhead yang ditentukan di muka adalah $\$ 8$ per jam tenaga kerja, kemudian biaya overhead pabrik sebesar $\$ 8$ dibebankan pada pekerjaan atau produk untuk setiap jam kerja yang dibutuhkan untuk menyelesaikan pekerjaan tersebut. Bila basis alokasinya adalah jam kerja langsung, rumusnya adalah sebagai berikut:

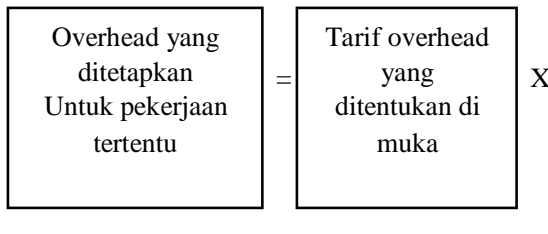

Menggunakan tarif overhead yang ditentukan di muka untuk menggambarkan tahapan yang harus dilakukan untuk menghitung tarif overhead yang ditentukan di muka, kita akan gunakan proses produksi yang berlangsung di Yost Precision Machining. Perusahaan memperkirakan biaya overhead pabrik total sebesar \$320.000 selama setahun dan total jam kerja langsung adalah 40.000. Tarif overhead pabrik yang ditentukan di muka untuk tahun tersebut adalah $\$ 8$ per jam kerja langsung. Perhitungannya adalah sebagai berikut :

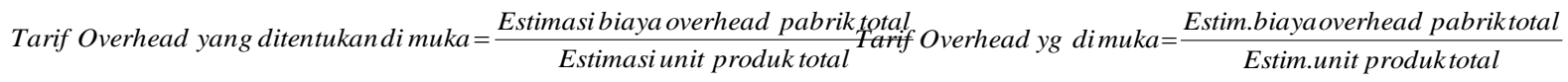

Tarif overhead yang ditentukan tersebut lebih didasarkan pada estimasi daripada yang aktual. Hal ini disebabkan oleh penghitungan tarif overhead yang ditentukan tersebut dilakukan sebelumnya dan digunakan untuk menetapkan biaya overhead sepanjang periode produksi. Proses membebankan biaya overhead pabrik ke produk disebut pembebanan overhead. Rumus untuk membebankan biaya overhead ke produk atau pekerjaan adalah sebagai berikut :

\section{$\frac{\$ 320.000}{40.000 J K L}=\$ 8$ perjam kerja langsung}

Overhead juga mungkin ditetapkan dengan pembebanan berdasarkan jam kerja langsung atau mungkin juga ditetapkan setelah pekerjaan diselesaikan. Perusahaan dapat memilih dua alternatif tersebut. Jika ada pekerjaan yang belum selesai pada akhir tahunm overhead harus ditetapkan juga dalam persediaan barang dalam proses. 
Pentingnya tarif yang ditentukan di muka. Bila perusahaan tidak menggunakan tarif yang ditentukan di muka, perusahaan harus menunggu sampai akhir periode akuntansi untuk menghitung tarif overhead aktual berdasarkan total biaya produksi dan total unit aktual selama periode tersebut. Ada beberapa alasan para manajer menggunakan tarif overhead yang ditentukan di muka daripada tarif overhead aktual :

Sebelum akhir periode akuntansi, manajer menginginkan untuk mengetahui penilaian sistem akuntansi terhadap pekerjaan yang diselesaikan. Sebagai contoh, anggaplah Yost Precision Machining menunggu sampai akhir tahun untuk menghitung tarif overhead. Para manajer akan mengalami kesulitan untuk menentukan harga pokok penjualan untuk pekerjaan sampai akhir tahun, meskipun pekerjaan telah selesai dan dikirimkan pada bulan Maret.

Jika overhead pabrik aktual dihitung beberapa kali, faktor musiman dalam biaya overhead dan basis alokasi dapat menimbulkan adanya fluktuasi tarif overhead. Para manajer merasa bahwa fluktuasi tarif overhead seperti itu tidak akan memberikan manfaat dan menyesatkan.

Penggunaan tarif overhead yang ditentukan di muka dapat menyederhanakan pencatatan. Untuk menentukan biaya overhead yang ditetapkan untuk suatu pekerjaan, staf akuntansi Yost Precision Machining dengan mudah mengalikan jumlah jam kerja langsung yang tercatat dengan tarif overhead yang ditentukan di muka sebesar $\$ 8$ per jam kerja langsung.

Karena alasan-alasan tersebut, sistem akuntansi biaya di sebagian besar perusahaan menggunakan tarif overhead yang ditentukan di muka daripada tarif overhead aktual.

\section{d. Memilih Basis Alokasi Biaya Overhead}

Basis alokasi yang digunakan bertindak sebagai cost driver biaya overhead. Coast driver adalah faktor seperti jam mesin, bed yang ditempati, waktu penggunaan komputer, jam terbang yang mengakibatkan adanya biaya overhead. Jika basis yang digunakan sebagai dasar untuk menghitung tarif overhead bukanlah cost driver, akan berakibat tidak akuratnya tarif overhead dan biaya produk akan terdistorsi. Sebagai contoh, jika jam kerja langsung digunakan untuk mengalokasi overhead, tetapi kenyataannya overhead tidak banyak berkaitan dengan jam kerja, sehingga produk yang membutuhkan banyak jam tenaga kerja akan memikul beban yang tidak realitis dan akan dibebani biaya terlalu tinggi.

Kebanyakan perusahaan menggunakan jam kerja langsung atau biaya tenaga kerja langsung sebagai basisi alokasi overhead pabrik. Di masa lalu, biaya tenaga kerja langsung memakan porsi $60 \%$ dari biaya produk dan biaya overhead hanyalah sepersekian saja dari sisanya.Situasi ini telah merubah dengan dua alasan. Pertama, peralatan otomatis yang canggih telah menggantikan peran para kerja langsung, karena biaya untuk mendapatkan dan memelihara peralatan tersebut diklasifikasikan sebagai overhead, biaya overhead akan meningkat sedangkan tenaga kerja langsung berkurang. Kedua , produknya sendiri semakin canggih, kompleks dan sering berganti-ganti. Peningkatan ini membutuhkan keahlian tinggi dari para tenaga kerja tidak langsung seperti para insinyur.

Jika di dalam perusahaan, biaya tenaga kerja langsung mengalami trend yang berkebali dengan biaya overhead pabrik, maka akan sangat sulit untuk menentukan bahwa tenaga kerja langsung menjadi "driver" biaya overhead. Sejalan dengan hal tersebut para manajer menggunakan prinsip activity-based costing untuk mendesain ulang sistem akuntansi biaya. Activity-based costing adalah teknik costing yang didesain untuk menghasilkan perhitungan overhead yang lebih akurat.

Meskipun tenaga kerja mungkin bukan basis alokasi yang tepat di dalam beberapa 
industri, tenaga kerja langsung tetap menjadi driver overhead yang signifikan. Kuncinya adalah bahwa basis alokasi yang dipilih oleh perusahaan harus benar-benar cost driver dan tenaga kerja langsung tidak selalu basis alokasi yang tepat.

\section{e. Perhitungan Biaya per Unit.}

Penetapan biaya overhead prabik sebesar \$216 di Yost Precision machining menghasilkan kartu biaya lengkap sudah. Ada dua tahap akhir. Pertama, total biaya bahan langsung, biaya tenaga kerja langsung, dan biaya overhead pabrik di pindahkan ke Ringkasan Biaya (Cost Summary) dari kartu biaya dan ditambahkan bersama untuk memperoleh total biaya. Total biaya (....) dibagi dengan total unit (2) untuk mendapatkan biaya per unit (...). Seperti sudah ditunjukkan sebelumnya, biaya per unit adalah rata-rata biaya dan tidak boleh diartikan sebagai biaya yang akan aktual terjadi bila unit lain dibuat. Kebanyakan overhead aktual tidak akan berubah jika unit lainnya dihasilkan, sehingga incremental cost dari unit tambahan tersebut akan lebih rendah dari rata-rata biaya per unit $\$ 900$.

\section{Hasil dan Pembahasan}

\section{Aliran BiayaPembelian dan Pengeluaran Material}

Pada tanggal 1 April, perusahaan memiliki baku \$7.000.00, selama bulan tersebut perusahaan membeli bahan baku senilai $\$ 60.000$. Pembelian tersebut akan dicatat dengan jurnal (1) sebagai berikut ;

Bahan Baku 60.000

\section{Utang Dagang 60.000}

Pengeluaran Bahan Langsung Dan Tidak Langsung selama bulan april dibutuhkan bahan baku sebanyak $\$ 52.000$ untuk produksi

Barang dalam proses 50.000

Overhead 2.000

\section{Bahan Baku 52.000}

Bahan yang dibebankan ke barang dalam proses menunjukkan bahan langsung untuk pekerjaan tertentu. Sebesar \$20.000 yang dibebankan ke overhead pabrik dalam jurnal (2) menunjukkan bahan tidak langsung yang digunakan dalam produksi selama bulan April.

Pengeluaran bahan langsung Kadangkadang bahan yang dikeluarkan dari rekening persediaan bahan baku terdiri dari bahan langsung saja.

\section{a. Biaya Tenga Kerja}

Karena pekerjaan dilaksanakan di berbagai departemen di Rand Company dari hari ke hari, kartu jam kerja diisi oleh para pekerja, dikumpulkan, dan dikirimkan ke departemen akuntansi. Di departemen akuntansi, jam kerja tersebut dibiayakan sesuai dengan tarif upah masing-masing pekerja dan biaya tersebut diklasifikasikan sebagai biaya tenaga kerja langsung dan tidak langsung.

Biaya tenaga kerja yang dibebankan ke overhead pabrik menunjukkan biaya tenaga kerja tidak langsung selama periode tersebut seperti supervisi, pengamanan dan pemeliharaan.

b. Biaya Overhead Pabrik

Seluruh biaya operasi pabrik selain bahan langsung dan tenaga kerja langsung diklasifikasikan sebagai overhead pabrik. Biaya - biaya ini dimasukkan ke rekening overhead pabrik secara langsung pada periode terjadinya.

\section{c. Pembebanan Overhead Pabrik}

Karena biaya manufaktur aktual dibebankan ke rekening pengendali overhead pabrik daripada ke barang dalam proses, bagaimanakan membebankan biaya overhead pabrik ke barang dalam proses ? Jawabannya adalah : menggunakan tarif overhead yang ditentukan di muka. Tarif overhead yang ditentukan di muka diperhitungkan pada awal tahun. Tarif tersebut dihitung dengan membagi estimasi biaya overhead pabrik total dengan 
estimasi total unit (diukur dengan jam mesin, jam kerja langsung, atau basis yang lain). Tarif overhead yang ditentukan di muka digunakan untuk membebankan biaya overhead ke pekerjaan. Sebagai contoh jika jam kerja langsung digunakan sebagai basis alokasi, biaya overhead dibebankan ke masing - masing pekerjaan dengan mengalikan jumlah jam kerja langsung untuk masing - masing pekerjaan dengan tarif overhead yang ditentukan di muka.

Rekening overhead pabrik berperan sebagai rekening kliring. Sebagaimana telah kita ketahui, biaya overhead pabrik aktual di debit ke dalam rekening pada saat terjadinya dari hari ke hari selama satu tahun. Pada interval tertentu dakam waku setahun tersebut, biasanya pada saat pekerjaan telah diselesaikan, biaya overhead dikeluarkan dari rekening overhead pabrik dan dibebankan ke rekening barang dalam proses dengan menggunakan tarif overhead uang ditentukan di muka.

\section{d. Harga Pokok Produksi}

Pada saat pekerjaan telah selesai, barang jadi ditransfer dari departemen produksi ke gudang barang jadi. Pada saat itu, departemen akuntansi akan membebankan bahan langsung, tenaga kerja langsung dan overhead pabrik yang ditentukan dengan tarif overhead yang ditentukan di muka ke pekerjaan atau produk. Transfer biaya - biaya ini harus dilakukan dengan sistem penentuan harga pokok yang paralel dengan transfer fisik barang - barang ke gudang barang jadi. Biaya untuk pekerjaan yang telah selesai dikeluarkan dari rekening barang dalam proses dan dimasukkan ke dalam rekening barang jadi. Jumlah keseluruhan yang ditransfer antara kedua rekening ini menunjukkan harga pokok produksi periode tersebut.

\section{e. Harga Pokok Penjualan}

Jika barang jadi dikirimkan ke konsumen untuk memenuhi pesanannya, biaya yang tercatat dalam kartu biaya digunakan sebagai dasar untuk memindahkan biaya barang yang terjual dari rekening barang jadi ke harga pokok penjualan. Jika barang jadi tersebut dikirimkan kepada konsumen karena pekerjaan telah dilaksanakan sesuai dengan permintaan konsumen maka ada dasar yang kuat untuk memindahkan seluruh biaya yang ada dalam kartu biaya ke dalam rekening harga pokok penjualan. Dalam banyak kasus hanya sebagian saja barang jadi yang langsung dikirimkan kepada konsumen.

\section{Job Orde Costing pada Perusahaan Jasa}

Job order costing juga digunakan dalam perusahaan jasa seperti kantor hukum, produser film, rumah sakit dan toko reparasi. Dalam kantor hukum, setiap klien adalah pekerjaan dan biaya yang terjadi diakumulasikan dalam kartu biaya sesuai dengan perkembangan kasus klien yang ditangani oleh kantor yang bersangkutan.

Proses Costing dan Job Order Costing; Dalam menghitung banyak biaya produk atau jasa, manajer dihadapkan dengan masalah yang sulit. Sejumlah biaya (seperti sewa) tidak mengalami perubahan besar dari bulan ke bulan sedangkan produksi selalu berubah - ubah sesuai dengan kegiatan produksi dari bulan ke bulan. Selanjutnya mengenai variasi produksi, perusahaan dapat memproduksi berbagai jenis produk dengan menggunakan peralatan yang sama. Dalam kondisi seperti ini, apakah mungkin dapat menentukan secara akurat biaya produk atau jasa ? Dalam praktik, pembebanan biaya ke produk dan jasa dilakukan dengan membuat rata -rata untuk antar waktu dan antar produk. Cara untuk membuat rata - rata sangat tergantung pada tipe proses produksi yang terkait. Dua sistem costing biasanya digunakan dalam manufaktur dan di sejumlah perusahaan jasa; kedua sistem tersebut biasanya disebut process costing dan job order costing.

Sistem process costing digunakan dalam perusahaan yang memproduksi satu jenis produk dalam jumlah besardalam jangka panjang. Prinsip dasar dari proses costing adalah mengakumulasikan biaya dari operasi atau departemen tertentu selama satu periode penuh 
(bulanan, kuartalan, dan tahunan) dan kemudian membaginya dengan jumlah unit yang diproduksi selama periode tersebut.

Singkatnya job order costing bersifat serba guna dan digunakan secara luas dan akan ditemukan di berbagai organisasi dengan berbagai macam produk dan jasa.

\section{Kesimpulan}

Informasi Akuntansi Manajemen ditujukan untuk menyediakan informasi akuntansi yang akurat bagi manajemen yang dalam pelaksanaan fungsi pokoknya sangat memerlukan informasi ini, terutama untuk perencanaan dan pengendalian bagi perusahaan. Informasi akuntansi manajemen dibagi menjadi yaitu :

Informasi akuntansi penuh (Full accounting information). Informasi akuntansi penuh dapat mencakup informasi masa lalu maupun informasi yang akan datang dan mencakup informasi mengenai biaya, pendapatan dan aktiva. Informasi akuntansi penuh selalu dihubungkan dengan kesatuan usaha, produk atau departemen karena informasi ini digunakan untuk pelaporan informasi keuangan dan analisis kemampuan menghasilkan laba rugi suatu divisi atau bagian secara khusus, pada bagian inilah informasi akuntansi perusahaan yang berisi informasi masa lalu digunakan.

Informasi akuntansi pertanggungjawaban (Full Responsibility Information) Tiap manajer dalam organisasi merencanakan aktiva, pendapatan dan biaya yang menjadi tanggungjawabnya dibawah koordinasi manajemen puncak dan menyusun programberdasarkan informasi akuntansipertanggungjawaban.Informasi akuntansi pertanggungjawaban juga digunakan untuk mengamati pelaksanaan anggaran dan menilai seberapa jauh manajer melaksanakan rencananya.

Informasi Akuntansi Diferensial (Differential accounting information) Informasi akuntansi diferensial mempunyai dua ciri utama, pertama informasi akuntansi merupakan informasi masa yang akan datang. Kedua, informasi akuntansi merupakan informasi yang berbeda diantara berbagai macam alternatif yang dihadapi oleh berbagai keputusan.Informasi akuntansi diferensial ini sangat diperlukan pihak manajemen dalam pengambilan keputusan sebagai pemilihan alternatif tindakan yang terbaik diantara alternatif yang tersedia, ditinjau dari segi pengorbanan dan manfaat yang diperoleh bila suatu alternatif tersebut diambil.

Akuntansi manajemen merupakan suatu sistem akuntansi yang tujuan utamanya yaitu untuk menyajikan laporan keuangan untuk suatu kepentingan pihak internal perusahaan, seperti manajer keuangan, manajer produksi, manajer pemasaran, dan pihak internal lainnya. Informasi ini sangat berguna sebagai pedoman untuk mengambil suatu kebijakan untuk masa yang akan datang yang berdasarkan data historis dari laporan keuangan

Mempelajari materi akuntansimanajemen juga takkan lepas dari manfaat yang didapat dari materi ini.Ada manfaat yang diperoleh perusahaan serta manfaat yang diperoleh manajer perusahaan serta oleh perusahaan secara keseluruhan. Berikut adalah manfaat yang akan diperoleh manajer perusahaan.

Peran akuntansi manajemen selanjutnya membantu penyusunan perencanaan yang efektif.Rencana ini umumnya disebut pula sebagai penganggaran. Dalam tiap program bisnis tentu dibutuhkan perkiraan dana yang dibutuhkan supaya kegiatan bisnis bisa terus berjalan. Maka dari itu, tiap kegiatan bisnis harus disertai estimasi anggaran dana yang dibutuhkan. Anggaran dana ini sendiri biasanya akan disiapkan per tahun serta bisa saja tidak sama antara satu perusahaan dengan perusahaan lain.

Adanya akuntansi manajemen juga akan membantu proses pengawasan serta pengendalian. Dalam Manajemen Bisnis, sangat mungkin terjadi penyimpangan seperti 
manajemen operasional tak sesuai standar, pengeluaran dana bisnis di atas anggaran, kesalahan prosedur kerja dan lain-lain. Aneka hal di atas akan menyebabkan kegiatan usaha menjadi tidak lancar serta berujung kerugian materiil. Proses pengawasan serta pengendalian sangat diperlukan agar hal-hal tersebut tidak terjadi. Manfaat akuntansi manajemen akan memberi suatu sistem informasi dalam mengatasi permasalahan terkait penyimpangan pada perusahaan.

Tujuan akuntansi manajemen selanjutnya adalah sebagai acuan operasional atas usaha sehari-hari guna mendapat sistem kerja efektif serta efisien. Hal ini akan dapat terpenuhi dengan adanya akuntansi manajemen. Manajer memiliki kebutuhan konstan akan informasi yang disediakan akuntan dalam memimpin serta menjalankan operasional perusahaan. Ada banyak kegiatan operasional manajer perusahaan yang menyandarkan program kerjanya agar tercapai pelaksanaan sistem kerja yang efektif, efisien serta tepat sasaran.

Akuntansi manajemen akan mempermudah proses pengambilan keputusan terkait penyelesaian masalah operasional perusahaan. Standar operasional prosedur yang diterapkan manajer umumnya tidak selalu berjalan mulus.Manajer perusahaan dituntut dalam menyelesaikan permasalahan yang muncul agar kerugian yang diderita tidak terlalu signifikan.Caranya ialah mengambil keputusan yang tepat melalui informasi dari akuntansi manajemen.Tanpa informasi ini, manajemen dapat kesulitan menentukan keputusan yang tepat.

\section{Daftar Pustaka}

Agustinus Sri Wahyudi, (1984), Organisasi, Kepemimpinan dan Perilaku Administarasi, Gramedia, Jakarta.

Agustinus Sri Wahyudi, (tth) Manajemen Strategik, pengantar proses berpikir strategik, Binarupa aksara Publisher

Daljono.(2004) Akuntansi Biaya. Perhitungan

Harga Pokok. Ba dan Penerbit Fakultas

Ekonomi Universitas Diponegoro,

Semarang,

Ernie Tisnawati Sule, \& Kurniawan Saefullah, (2005).Pengantar Manajemen, Edisi

Pertama. Penerbit Kencana. Jakarta

Firdaus A. Dunia, SE., (1999) Pengantar Akutansi 1 \& 2, Lenbaga Penerbit Fakultas Ekonomi Universitas Indonesia'.

Garrison/Noreen

Akuntansi

Manajerialditerjemahkan A.Totok Budi

Santoso,SE, Akt.Mulyadi, Akutansi Manajmen

Hadari Nawawi, (2011), Manajemen Sumber

Daya Manusia, Gaja Madah University Press. Yogyakarta.

Husin Umar, Strategic Managmen, Jakarta, PT. Gramedia Pustaka Utama, 2003.

Jujun S Suriasumantri, (2007), Filsafat Ilmu sebuah Pengantar Populeh, Pusaka Sinar Haraapan, Jakarta,

Kasdin Sihotang, Febiana Rima K., Benyamin Molan, Rodemeus Ristyyantoro, (2012), Critical Thingking Membangun Pemikiran Logis, Pustaka Sinar Harapan, Jakarta

Konsep, Manfaat dan Rekayasa Edisi 3

Malayu Hasibuan, S.P.(2000).Manajemen

Sumber Daya Manusia.Edisi revisi. : Penerbit PT. Bumi Aksara. Jakarta

Malayu Hasibuan, S.P.(2001).Manajemen : Dasar, Pengertian, Dan Masalah,Edisi revisi. Jakarta : Penerbit PT. Bumi Aksara.

Muhammad Idris DM, (2010), dasar-dasar Ilmu Filsafat, STAI-MU, Tanjungpinang

Mulyadi , Universitas Gajah Mada Yogyakarta, 2001

Oteng Sutisna, (tth), Administrasi Dasar teoritis untuk praktek Profesional, Angkasa, Bandung.

Peter Druker, tth, Manajmen ; Tugas, Tanggung Jawab , Peraktek,PT. 
Gramedia Pustaka Utama, Jakarta.

Rolan O'relly, 2004, Manajemen Sumber Daya Manusia, Persetasi Pustaka Publisher, Jakarta.

Salemba Empat, Mcgraw - Hill Companies,(2000) Akuntansi Manajemen,Inc..

Soeleman Sukmalana, (2010), Perencanaan SDM-Human Rosources Planning, Pustaka Pengembangan Bisnis PT. Intermedia Personalia Utama, Jakarta.

Soemarso RS.(1994) Akutansi, Suatu Pengantar, edisi keempat, Buku II Lembaga Penerbit. FEUI,.

Sri Wiludjen SP , (2007).Pengantar Manajemen. Edisi Pertama,Penerbit Graha Ilmu, Yogyakarta.

Stephen Robbins P, Timothy A. Jugde, (2007),Perilaku Organisas, Salemba Empat, Jakarta.

Veithzal Rivai \& Ahmad Fauwzi Mohd. Basri (2005),Performamce Appraisal, PT. Raja Grapindo Persada, Jakarta,

Winardi.J (2004).Manajemen Perilaku Organisasi, ( edisi revisi) Penerbit Prenada Media. Jakarta 